\title{
Lived Experiences of Online and Experiential Learning Programs in Four Undergraduate Professional Programs
}

\author{
Kathy Snow, Leslie Wardley, Lorraine Carter, Pat Maher
}

This paper presents the observations and reflections of four faculty members who developed experiential online learning pathways for students in diverse professional programs. In relation to programmatic expectations of Nursing, Education and Business, the challenges and opportunities for experiential online learning design are discussed. In addition, the scaffolding and development of online learning within an undergraduate degree, which ladders into professional programing, are presented. Using Kolb's Experiential Model of learning design to structure the discussion, the faculty members reflect on the success of implementation from their various positions as leaders and instructors of programs. They seek to answer questions for themselves and their faculties in relation to the feasibility of designing experiential learning opportunities online and how this can contribute to deepening professional practice. The paper closes with implications for practice for other post-secondary educators who may be considering experiential online learning.

Notre article présente les observations et les réflexions de quatre enseignants qui ont mis au point des parcours d'apprentissage expérientiel en ligne pour des étudiants inscrits dans divers programmes professionnels. Nous discutons des difficultés et des possibilités de l'apprentissage expérientiel en ligne par rapport aux attentes des programmes de soins infirmiers, d'éducation et de commerce. De plus, nous présentons la construction et l'élaboration de l'apprentissage en ligne dans un programme de premier cycle universitaire qui conduit à l'élaboration de programmes professionnels. En utilisant le modèle expérientiel de conception de l'apprentissage de Kolb pour structurer la discussion, les enseignants réfléchissent aux réussites dans la mise en cuvre de leurs différentes fonctions de chefs de programme et d'instructeurs. Ils se posent des questions - pour leur propre compte et pour les enseignants - sur la faisabilité de la conception d'apprentissages expérientiels en ligne et se demandent comment cela peut contribuer au perfectionnement de leur pratique professionnelle. Nous nous penchons enfin sur les conséquences de notre étude pour la pratique d'autres éducateurs, au niveau postsecondaire, qui envisagent peut-être l'apprentissage expérientiel en ligne. 
$\mathrm{E}$ xperiential education is a pedagogical approach that encourages collective and personal critical reflection and development (Vince \& Reynolds, 2007). In the literature that documents the learning needs of students in professional programs in post-secondary contexts, critical reflection and lifelong learning emerge as essential elements in the development and growth of students (Holman, Smith, \& Welch, 2009). Although one might expect to see many examples of experiential education in professional programs, the practical realities of experiential education in higher education are challenging, and faculty interested in developing experiential learning opportunities for students must negotiate institutional policies, external regulatory bodies, and, at times, even concerns about legitimacy within their departments.

While extensive logistical and coordination practices, coupled with quality assurance measures, have generally enabled universities to meet these challenges largely through internships and practical field experiences, students may be placed far from their home institutions, a situation that limits their opportunities to reflect on experiences with colleagues. Enablement of sharing among students has, to date, been a particular challenge of experiential learning.

Online education in professional programs is changing the higher education landscape. Online education has introduced both opportunity for deepening experiential learning, as well as challenges for legitimizing its use in programs that demand extensive experience. In an exploration of the opportunities and challenges of supporting experiential learning via technology, we have reflected on our practices in curriculum design and delivery in relation to online experiential opportunities in four disciplinary perspectives: nursing, education, business and community studies. The latter program is frequently completed prior to social work and policing. Our reflection is grounded in the question: How can the learning practices associated with experiential learning in professional programs be (re)created in an online environment? While we acknowledge the limitations of online education, we propose that experiential learning in online professional programs can be accomplished with integrity. Moreover, such learning supports professionals who must work in today's technologysupported and information-saturated workplaces.

\section{A Brief Review of Literature}

This paper brings together the following challenging areas for many educators:

1. Understanding and designing experiential education within the confines of higher education;

2. The limitations of learning design for professional programs; and

3. The role of online learning within professional programs and in relation to experiential education.

We have positioned our exploration of online experiential education using various understandings, described below.

\section{Experiential Education Framework}

Experiential education as a teaching and learning approach is undergoing a revival (Penger, Znidarsic \& Dimovski, 2011). The term itself has broad meaning and is often misunderstood or misapplied through reductionist thinking to any learning that involves activity. For example, an apprenticeship may or may not be a formal experiential learning event, depending on how it is structured (Reynolds, 1999). The key component of experiential education documented in the literature is action on the part of the student that promotes learning through reflection. Notably, it is reflection that is often missing from programs claiming to be experiential in nature. Dewey (1933) noted that experience itself is not always educative. Instead, in order to appreciate the significance of the learning experience, reflection 
must occur. First introduced by Kolb and Fry (1975), the term experiential learning refers to a set of techniques that provide individuals with encounters from which they can learn and develop. Experiential learning theory based on Kolb (1984) suggests that it is a "process whereby knowledge is created through the transformation of experience. Knowledge results from the combination of grasping and transforming experience" (p. 41). Kolb further proposed that experiential learning is experienced as a cycle of four stages: concrete experience, reflective observation, abstract conceptualization, and active experimentation. While there are other understandings of experiential learning in the literature and in practice, Kolb's work has stood the test of time and is generally accepted as the most influential theory of experiential learning (Kayes, 2002).

\section{Professional Programs}

Professional programs in higher education, such as nursing, social work, education, and business, face specific challenges in curriculum design (Young, 2018). Like other undergraduate and graduate programs, faculty must teach large amounts of content in what can feel like too short of a term, as well as teach problem solving, critical thinking, and discipline-related skills. At the same time, professional programs involve higher stakes than other undergraduate programs because students must acquire specific skills before graduation. Examples include foundational surgery skills for medical students, intravenous insertions for nursing students, and safe management of groups of active young people for students in education. Graduates are expected to emerge from their programs as professionals in their respective fields, with values and skills including but not limited to ethics, communication, and risk management. In an examination of medical school graduates over a tenyear period, unprofessional behaviour was noted as the reason for $95 \%$ of all disciplinary actions involving recent graduates (Papadakis et al., 2004). Although the importance of these so-called "softer" skills is well recognized in the curricula of professional programs, instruction related to and assessment of these skills remain problematic (Knopp, 2006).

Some students in professional programs may not fit the stereotype of the traditional learner who enters university directly from high school. Many students in professional programs return to school after reaching a plateau in their careers while others may be pursuing a second degree (Courtney, 2018; Sloane-Selase \& Kopps, 2013). These factors add to the challenges of experiential learning. For example, according to Ewert and Sibthorp (2009), within experiential education, there is a wide range of issues which can influence evidence-based learning outcomes, including:

1. Precursor variables existing before the experience (e.g., prior knowledge, demographics, motivations and expectations)

2. Concomitant variables occurring during the experience (e.g., group characteristics, situational impacts and conflicting demands); and

3. Post-experience variables occurring after the experience (e.g., post experience exhilaration and response shift bias).

Returning adult learners are affected by all three kinds of variables, but the category of precursor variables may be especially influential when there is substantive life and work experience before the student enrolls in a professional program.

A further distinguishing feature of a professional program is its reputation, which depends principally on how well its graduates perform, either on certifying exams and/or in job placements. Some students, for example, might enter a program as top candidates because of their ability to prepare for tests and formal assessments, but they may not have or be able to demonstrate the professional skills associated with the practice field. In addition to acquiring 
knowledge and professional competencies, students must develop an internalized proactive commitment to professional development. Through judicious professional development, the individual progresses towards excellence that is reflective of the discipline and furthers the activities of the discipline (Hamilton, 2014).

\section{Online Learning and Experiential Education}

Online collaborative activities enabled by synchronous and asynchronous technologies have been shown to support the development of competence in professional communication (Salzman et al., 2016), independent learning (Broadbent \& Poon, 2015), and transcultural competencies (Mikkonen et al, 2016). These capacities underscore the possible value of online tools and approaches in relation to experiential learning.

Although the benefits of online tools in the support of experiential learning are emerging in the literature, there is some disagreement about how much technology can and should be used in professional programs. For example, at present, a fully online teacher education program cannot exist in Canada. In part, this is due to the complex network of regulatory bodies that govern teacher education. It is also due to the idea that teacher education cannot be effectively accomplished in an online setting since the training of teachers is largely seen to be experiential in nature (Jaggars \& Bailey, 2010). The same views are held regarding other professional programs such as nursing and, to some extent, business. Conversely, in discussing engineering and medical training, Bates (2009) emphasizes the access to education that online education affords for students in remote and rural areas and suggests that learning centres can serve as settings for the handson learning critical to professional competency.

In summary, experiential education offers potential to strengthen professional competencies while online learning has recently emerged as a valuable means of developing these competencies. However, the complexities of organizing and delivering experiential opportunities in general, and in online settings in particular, are significant as are the legitimacy and oversight questions posed by various external regulatory bodies.

\section{Four Iterations of Online Experiential Learning in Professional Programs}

Over the next few pages, we will present our perspectives on four undergraduate-level professional programs that involve experiential learning to varying degrees. Our perspectives are influenced by our lived experiences and responsibilities within our small teaching-intensive universities in Nova Scotia and Ontario. The first scenario is narrated from an administrative and programmatic perspective, namely, that of a Director of Nursing. The subsequent reflections explore courses in education, business, and community studies and are narrated from the faculty perspective.

\section{Scenario 1: Nursing Education, RPN to BScN Blended Learning Program}

During my time as Director of Nursing at the Institution, I was responsible for three different undergraduate nursing programs. The program described here is the Registered Practical Nurse $(\mathrm{RPN})$ to Bachelor of Science in Nursing $(\mathrm{BScN})$ degree program. Through this program, Registered Practical Nurses (RPNs) study part-time in pursuit of a Bachelor of Science in Nursing degree (BScN). The majority of learners in the program are working adult learners who are balancing work, family, community, and other responsibilities.

A number of theoretical tenets and contemporary realities of $21^{\text {st }}$ century nursing are important to this discussion. The first is that learning about nursing at 
the baccalaureate level requires the nurse-learner to be a skilled critical thinker in the clinical setting (College of Nurses of Ontario, 2014). Additionally, the choices that nurses make at the point of care are increasingly based on the use of information technology (Strudwick, 2015). Excellence in critical thinking and online information gathering, synthesis, and analytic skills are core to the work of the registered nurse.

The RPN to $\mathrm{BScN}$ program discussed here is a blended learning program. Theory courses are delivered online and clinical (experiential) courses occur in clinical practice settings. While a person might surmise that there is little or no online activity in the clinical courses, this is not the case. Each clinical course includes an online course site which, in addition to housing resources, serves as an environment where students are required to reflect and think critically on their learning with their clinical instructor and other students. This work happens principally through writing. Tools such as discussion boards, blogs, and course-specific email are central to these courses.

The literature on the connections between reflection, critical thinking, writing, and nursing education is growing. There is extensive research on the relationships between thinking and writing as it pertains to nursing education. Belinski (2002) described the "writing to learn paradigm," with its emphasis on "personal transformation," as an important tool in fostering critical thought and concept clarification. The 1980s and 1990s saw a distinct shift in nursing practice from a largely taskoriented to a more holistic model (Carter 2008a, 2008b; Ironside, 2004). Given this shift, today's nurses and nursing students, including those in the $\mathrm{RPN}$ to $\mathrm{BScN}$ program, need many formal and informal occasions to reflect and think critically. The blend of clinical learning with carefully designed online writing activities is a powerful combination. Such activities not only deepen the nursing student's thinking processes in the clinical setting, but they also foster engagement with peers (Killam, \& Carter,
2010) and structured thinking about practice (Carter, 2008a, 2008b).

The RPN to BScN blended learning program is built on a foundation of evidence-based knowledge and the principles and practices of experiential learning. For example, case studies and problem-based learning activities in the nurse-learner's theory courses serve as a form of experiential learning. Alternately, the clinical or experiential courses are enhanced through online activities and assignments that require critical thinking through reflection. Thus, in both kinds of courses, the online learning setting facilitates the key elements of experiential learning: interaction with content and ideas; feedback from other students, clinical instructors, and nursing faculty; reflection and critical thinking; and understanding and meaning by individual nurselearners.

Nurse-learners consider the literature on experiential learning and understanding and creating meaning to be important. For example, Strudwick (2015) describes how nurses transition to the use of technology as well as how they value experiential learning. Patterson and Snelgrove-Clarke (2016) explore how journaling can enable personal learning in the online setting. Nurse-learners can track and monitor their own progress, and, thus, create personally significant learning environments. Literature on online education also shows that concept-based learning supports deep learning (Nielsen, 2016).

Sound pedagogical and design choices are the best predictors of meaningful experiential learning in nursing (Carter, Salyers, Myers, Hipfner, Hoffart, MacLean, White, Matus, Forssman, \& Barrett, 2014). In the RPN to $\mathrm{BScN}$ blended learning program, methodologies such as the Introduce, Connect, Analyze, Reflect and Extend (ICARE) model (Salyers, \& Carter, 2010) and the Conscious Curriculum Design and Development (CCDD) model (Beattie, \& Carter, 2018) optimize experiential learning, lead to significant learning experiences for 
students (Fink, 2013), and ensure a connected curriculum (Fung, 2017).

\section{Scenario 2: Teacher Education, Elementary Education, Science Methods}

This scenario is based on a course design I developed and launched for students in an elementary teacher education science methods course composed of two cohorts: a campus-based cohort of 20 students and a second First Nations cohort located off campus consisting of students from four First Nations communities in Nova Scotia. The blended learning design of the course was selected to enable local inschool experience for the First Nations students, some of whom were working as teacher assistants and all of whom were living in the community. A secondary goal of the learning design was to connect campus and community students in order to build relationships and transcultural understandings between the cohorts.

The course was divided into four parts. Each part began with a face-to-face meeting during which the objectives for the section were presented, and a debrief or reflection on the previous section. In the first face-to-face meeting, time was used for introductions, team building, and sharing of administrative information.

The students then moved into the online and practical aspects of the course. Students completed their activities online from their homes, often integrating learning directly into their current working contexts to achieve the educational objectives outlined at the beginning of the cycle. The typical learning cycle followed the format outlined in Table 1.

Table 1. Typical learning yycle, teacher education, science

\begin{tabular}{|l|l|l|l|}
\hline Reflective Observation & $\begin{array}{l}\text { Abstract } \\
\text { Conceptualization }\end{array}$ & Active Experimentation & Experience \\
\hline $\begin{array}{l}\text { The first lesson of each } \\
\text { unit was a face-to-face } \\
\text { lesson in which the } \\
\text { previous experience was } \\
\text { deconstructed and } \\
\text { explored and a new cycle } \\
\text { established. }\end{array}$ & $\begin{array}{l}\text { Activities were used to } \\
\text { engage with theory } \\
\text { related to learning } \\
\text { objectives. }\end{array}$ & $\begin{array}{l}\text { Each lesson design was } \\
\text { unique to student and } \\
\text { context. community }\end{array}$ & $\begin{array}{l}\text { Students did online } \\
\text { video presentations of } \\
\text { their lessons and } \\
\text { received feedback from } \\
\text { their classmates. }\end{array}$ \\
\hline
\end{tabular}

I supported students in their reflection by asking questions and adding supportive comments through the online platform. Students' practice of reflection was deepened by my support. I was also available by email and in a face-to-face setting for conversations that students did not want to share publicly. I was especially struck by the level of discussion and questions about the use of media in the course. Students created videos of their teaching and learning environments, which allowed many non-First Nations students to see the homes and communities of First Nations students for the first time. Transcultural competency for students in both cohorts was increased through sharing sessions based on the students' independent lessons. Formal and professional online communication, a critical element of development for novice teachers, was modeled and supported through asynchronous 
discussions. Such modeling would not have occurred in a fully face-to-face offering. Finally, resource preparation, the creation of materials, and the requirement that students record their lessons supported objectives pertaining to technological development and resource development. The students appeared to consider their public sharing of materials to be a 'higher stakes' activity than an assignment submitted only to the instructor. Though potentially stressful, this allowed a more realistic experience as novice teachers often feel trepidation around public speaking upon encountering their first full classroom of students.

\section{Scenario 3: Business, Occupational Health and Safety}

The Association to Advance Collegiate Schools of Business International (AACSB) has become an accrediting agency for degree programs in business that enhances the reputation of business schools. Although the business school discussed in this scenario is not AACSB accredited, business programs across Canada including the one discussed here are influenced by its guidelines (Elliott, 2013) which recommend experiential learning as a means of bridging academic competencies with workplace needs (Burch, Heller, \& Freed, 2014).

In this scenario, I taught an Occupational Health and Safety course as a fully online course with support from the university's Centre for Teaching and Learning. The degree program in which this course is housed offers students the flexibility to complete their studies in three ways: online, on-site, or as a combination of the two in a hybrid format.

As a faculty member, I have taught multiple sections of this online course since its inception and made various modifications based on student feedback and my own observations. The course offering under discussion involved 40 students. Students came from diverse disciplinary backgrounds including business (55\%), nursing (23\%), and the arts and sciences $(22 \%)$.

The principal goal of the course is the development of students' knowledge through readings, case studies, a research assignment, and tests. This knowledge is deepened through interactions with classmates, reflective blogging, and promotional videos focused on occupational health and safety, and created collaboratively with community members.

Blog entries were completed during three specific time periods corresponding with the course's modular framework. Students were responsible for creating a blog that offered background research and presented informed insights and reflections on a topic related to the content of a designated module. They were also asked to challenge or elaborate on the views of others in their blog entries. In short, students were asked to complete activities off-line and then share their experiences with the other members of the class online.

As in the course that focused on teacher education (discussed above), each unit followed a specific learning cycle which is presented in Table 2. 
Table 2. Typical learning cycle, occupational health and safety

\begin{tabular}{|l|l|l|l|}
\hline \multicolumn{1}{|c|}{$\begin{array}{c}\text { Reflective } \\
\text { Observation }\end{array}$} & \multicolumn{1}{|c|}{$\begin{array}{c}\text { Abstract } \\
\text { Conceptualization }\end{array}$} & \multicolumn{1}{c|}{$\begin{array}{c}\text { Active } \\
\text { Experimentation }\end{array}$} & \multicolumn{1}{|c|}{ Experience } \\
\hline $\begin{array}{l}\text { Interactive learning } \\
\text { based on content of } \\
\text { module }\end{array}$ & Research paper & $\begin{array}{l}\text { Discussion posts, blog } \\
\text { entries \& case studies }\end{array}$ & $\begin{array}{l}\text { Community-based } \\
\text { marketing outreach } \\
\text { message }\end{array}$ \\
\hline $\begin{array}{l}\text { Simulations and } \\
\text { videos posted by } \\
\text { professor with } \\
\text { questions to address } \\
\text { in blogs }\end{array}$ & $\begin{array}{l}\text { Conceptualizing } \\
\text { korkforce-relevant } \\
\text { knowledge related to the }\end{array}$ & $\begin{array}{l}\text { Reflecting, applying } \\
\text { knowledge, and } \\
\text { evaluating peers }\end{array}$ & $\begin{array}{l}\text { Content presented } \\
\text { online; three-tiered } \\
\text { monitoring and } \\
\text { measurement systems } \\
\text { (peers, professor, and } \\
\text { community members) }\end{array}$ \\
\hline
\end{tabular}

As noted earlier, measuring the effectiveness of experiential education can be challenging because of diverse factors including participants' backgrounds, program and course designs (online or on-site designs), and individual program experiences (Ewert, \& Sibthorp, 2009). While I recognize the impact of these and other variables in terms of measuring experiential learning, these confounding variables actually appeared to improve the experiential learning experience for students and community members.

First, the asynchronous nature of the course enabled students from various educational and work backgrounds to enroll in it. This diversity enhanced the learning environment since working professionals from across the country were able to share their workplace experiences and expertise. In addition, some students who could not offer knowledge contributed in other ways, such as their skill with technology and social media platforms. Community members gained access to students who would normally be inaccessible, while the students developed expertise in coordinating workplace health promotion programs in technology-supported ways. This skill is required in distributed organizations and contexts involving remote locations and limited physical contact.
Second, online postings displayed significant depth and breadth because students could control when they responded to others' entries. Often, the blog entries blended theory with personal reflections and on-the-job experiences. Frequently, students reflected and constructed their knowledge before engaging in discussion. This strategy enabled confidence building and assessment of the validity of postings before they were shared. It also meant that students' work displayed depth as they incorporated relevant links to websites and provided online support materials. Some discussion threads started at the beginning of the course were incorporated throughout the course and modified as students acquired new knowledge.

The group media outreach project provided a further level of experiential learning with students taking their course-based learning into practice within the community. Often, what they thought would work in theory did not work in practice and required working collaboratively with others. This collaboration process with community members represented another level of reflective experience as students shared their lessons in their groups and blog entries.

In the course, the online environment appeared to enhance students' reflective practices. Students used theoretically-based research and case studies that 
supported their problem solving and critical thinking skills. In turn, they incorporated these skills into experiential activities with other students and community members.

\section{Scenario 4: Community Studies, Work Placement Courses}

This scenario is based on my experiences in 2015 revising two work placement courses in a degree program focused on community. While community studies is not regarded to be a professional program in itself, it has a longstanding relationship with two fields of professional practice: policing and social work. Composed of 30 credits of study, the Bachelor of Arts Community Studies (BACS) degree at the Institution often leads to or follows a student's study in one of these two areas. In the case of policing, a BACS degree is often a post-practice degree undertaken when a police officer strives to move up the management ranks. For a full discussion of the BACS degree and its scaffolding of courses, see Connell and Seville (2007), Maher and Root (2015a; 2015b), and Callary, Maher, Root, and Ryan (2018).

Experiential learning is one of the key pedagogical approaches used in this program. The two work placement courses that I will discuss follow a full year introductory course focused on learning how to learn. These placement courses have been a part of the program since its inception in 1975. The primary purpose of the courses is the following: "To give students the opportunity to develop skills and to be made aware of how problems are analyzed and solved in the real world" (Morgan, 2004, p. 72). The courses have also played a role in positioning the degree within the community and establishing its identity as an applied degree. Building on their long standing, the courses experienced substantive change in 2015: they went fully online.

The syllabus for one of the two courses states that the course is "designed to provide you with the opportunity for meaningful career exploration and the possibility of gaining skills in a field of interest.... [it] provides an opportunity to experience potential careers while still working on other classes towards your degree and initiating your thoughts on the professional life choices ahead." Thus, the course is different from a co-op in that it is completed simultaneously with other courses. In the second work placement course, students are provided an opportunity to solidify their chosen professional path through a similar placement experience. The purpose of this course is three-fold:

1. To provide practical work experience;

2. To enable the student to test his or her potential career choice; and

3. To provide opportunities for the student to reflectively link theory and practice.

The courses are experiential in nature with assignments that reflect the four components associated with experiential learning. As in the earlier scenarios, each unit followed a specific learning cycle which is presented in Table 3. 
Table 3. Typical learning cycle, work, placement courses

\begin{tabular}{|l|l|l|l|}
\hline \multicolumn{1}{|c|}{$\begin{array}{c}\text { Reflective } \\
\text { Observation }\end{array}$} & \multicolumn{1}{c|}{$\begin{array}{c}\text { Abstract } \\
\text { Conceptualization }\end{array}$} & \multicolumn{1}{c|}{$\begin{array}{c}\text { Active } \\
\text { Experimentation }\end{array}$} & \multicolumn{1}{|c|}{ Experience } \\
\hline $\begin{array}{l}\text { Discussion posts } \\
\text { and a final reflective } \\
\text { essay for each } \\
\text { course }\end{array}$ & $\begin{array}{l}\text { Developing a career plan } \\
\text { COMS 2101); information }\end{array}$ & $\begin{array}{l}\text { Discussion posts, } \\
\text { journal summaries, \& } \\
\text { self/supervisor } \\
\text { evaluations }\end{array}$ & $\begin{array}{l}\text { Placements with a } \\
\text { community partner (100 } \\
\text { hours for COMS } \\
\text { 2101,100 hour for } \\
\text { COMS 3101) }\end{array}$ \\
\hline
\end{tabular}

The purpose of the 2015 course re-design was to foster community and enable flexibility. Prior to 2014, the courses had been running for at least 10 years without significant change. Although students were connected with a faculty member or student placement officer, they were largely independent learners. They did not belong to a cohort through which they could discuss similar issues or challenges. Additionally, workload was significant for the faculty and placement officer. Because of these circumstances, the decision was made in 2014 that the students in the courses would join a class with inperson lecture hours which would bring them together. This approach, however, proved to be challenging because of the growing diversity of the students' placements across Canada and internationally.

A year later, transitioning the courses to a fully online format solved the challenges of flexibility and geographic diversity. That year, 72 students started their placement courses. While they completed their placements in different physical locations, they connected as a group and learned from each other through the online setting. Results have been highly favourable: while faculty are responsible for two courses under the new model, students operate as a single cohort. Students are enrolled into the courses twice a year (September and May) and provided two semesters to complete each course.

In summary, the transition of the course to an online setting has enabled the sharing of experiences and a sense of community among the students. It has also provided significant flexibility. Currently, students discuss units together, find placements together, turn placements into real work opportunities post-degree, and realize that they are part of a likeminded community.

\section{Discussion of Learning Design, Online Experiential Learning, and Implications for Students}

Although the observations offered in this paper are limited to the reflections of a single administrator and three faculty members on learning design and the impacts these designs have had on students, our experiences have generated a number of themes worth consideration by other educators navigating the realities of online professional programs and experiential education. Five themes are discussed below.

\section{Technology Skills}

An obvious benefit for students in professional programs who study online is that they develop technology and information competencies in line with the requirements of their future professions. For instance, in the courses described here, future teachers and business professionals were asked to develop and share multimedia assets including videos and interactive online presentations, as well as compose email and message board responses. 
Working with technology is critical in both of these professions. Such skill is equally important in nursing where nurses are required to consult and critique information they gather through diverse technologyenabled means and make evidence-informed decisions at the point of care. When the development of technology skills is integrated with learning and serves as a means to an end, students' acquisition of technological skills is reported to be more effective than targeted teaching of the same skills (Sung, Chang, \& Liu, 2016).

\section{Professional Communication Skills}

Professional communication skills are among the most critical skills that students can develop in the online learning setting (Belinski, 2002). In all of the disciplines represented in this paper, working professionals are required to communicate with assorted internal stakeholders and the wider community on a daily basis. Hence, refining these skills while a person is a student is important. When students do not interact physically, professionalism in their communication may be greater than it would be in a face-to-face context. In the online setting, students may experience greater growth as communicators in that they do not have the same access to an instructor to facilitate exchanges.

\section{Connections with the Professional}

\section{Community and the University Campus}

In each of the scenarios described above-nursing, education, business, and community studiesstudents' experiential learning opportunities involved geographical distance from the university campus. Students on placement can serve as ambassadors for their universities and programs as well as conduits of information back to their main campuses through the tools of online learning. The online aspects of their courses enable the construction of community with peers and instructors.

\section{Self-Directed Learning Skills}

Instructors who provide their students with online asynchronous environments, punctuated with critical deadlines, create space for students to develop time management and self-directed learning skills. While nursing students are always busy and often stressed when they are in clinical settings, the requirements to make contributions to a discussion board and to submit assignments according to pre-determined deadlines keep them in touch with their peers, instructors, and the program as a whole. In the case of the education students, the gap between the faceto-face sessions challenges them to participate in teaching practice and to record and share their experiences. This kind of expectation prompts students to engage in self-directed learning and parallels what will be expected of them as practitioners. At the same time, because skilled instructors pace their assignments and activities, students learn how to be reflective thinkers over time and before they are faced with the hectic nature of professional practice.

\section{Connections Between Theory and Practice}

Experiential education has long been recognized for bringing theory and practice together and deepening learning. We would also suggest that the inclusion of online components reflects realistic practice. Using an online format, students are able to experience their learning in situ and share it with others through recordings, re-telling of experiences, informal and informal reflective activities, and carefully designed assignments. The online medium enables students to leave the boundaries of the campus and experience real practice in the field.

\section{Transcultural competencies}

Considering the cultural cohorts described in the education scenario, the opportunity to provide a safe space for each group to be grounded and to come together for a sharing of culture and experience was 
especially meaningful. Through separate and shared reflections, the students experienced a greater depth of cultural understanding than they would have otherwise.

The online elements in the highlighted nursing program also facilitate cultural understandings including how health services and issues of access differ across the province of Ontario. The online environment connects registered practical nurses with many years of experience and new grads. Through this coming together over physical distance and through technology, the nursing students learn about the cultural and professional practices of nursing in diverse settings and at different points on the novice to expert spectrum.

Such development is critical in fields such as education and nursing where in-depth understanding of diversity is necessary in daily practice. The chance to experience others' perspectives, lifestyles, and varied ways of being in the world and to reflect on all of this in the safety of a supportive online learning setting should not be underestimated.

\section{Final Thoughts}

Although we do not recommend online learning as the only solution to the desire for experiential learning in professional programs, it does hold considerable promise. Through thoughtful design and delivery of an online experience, the online setting can play an important role in skills development and fostering an authentic learning experience. It can also encourage communitybuilding since learners can be in different locales but still connect, reflect, and share. Further, online settings can enable the growth of communication, media, and information gathering skills all of which are important in a person's professional life. Finally, the advantages of critical reflection on real life experiences through judicious written and real time expressionare well established in the literature.

\section{References}

Bates, T. (July 5, 2009). Blog: Can you teach real engineering at a distance? Retrieved from: https://www.tonybates.ca/2009/07/05/ca n-you-teach-real-engineering-at-a-distance/

Beattie, B., \& Carter, L. (In press). Blending 'tradition' with 'new' ways in online learning: Emerging pedagogies and design models for nursing education. In Global best practices in online teaching and learning - Around the world in 30 bites. Eds. M. S. Makhanya, \& D. Singh. Pretoria, South Africa: Unisa Press.

Broadbent, J. \& Poon, W.L. (2015). Self-regulated learning strategies and academic achievement in online higher education learning environments: a systemic review. The Internet and Higher Education 27(October 2015),1-13.

Burch, G. F., Heller, N. A., \& Freed, R. (2014, March). Back to the basics: Developing a student engagement survey to evaluate the role of experiential learning on student engagement. In Developments in Business Simulation and Experiential Learning: Proceedings of the Annual ABSEL conference (Vol. 41).

Callary, B., Maher, P.T., Root, E.L., \& Ryan, J. (2018). Exposition of process-based learning for first year university students. Collected Essays on Learning and Teaching, 11, 118-128.

Carter, L. M., Salyers, V. Myers, S., Hipfner, C., Hoffart, C., MacLean, C., White, K., Matus, T., Forssman, V., \& Barrett, P. (2014). Qualitative insights from a Canadian multiinstitutional research study: In search of meaningful e-learning. Canadian Journal of Scholarship of Teaching and Learning, 5(1).

Carter, L. (2008a). Critical thinking dispositions in online nursing education. Journal of Distance Education/Revue de l'Éducation à Distance, 22(3), 89-144. 
Carter, L. (2008b). Perceptions of writing confidence, critical thinking, and writing competence among registered nurselearners studying online. Canadian Journal of University Continuing Education, 34(2), 63-87.

College of Nurses of Ontario 2014, Competencies for entry-level Registered Nurse practice, viewed 14 May 2015 , http://www.cno.org/Global/docs/reg/4 1037_EntryToPractic_final.pdf

Connell, J. \& Seville, P. (2007). Process-based learning: A model of collaboration. In A. Hajek \& E. Noseworthy (Eds.). Proceedings of the Association of Atlantic Universities 11th Teaching Showcase; October 28 2006, Memorial University of Newfoundland, St. John's, NL (pp. 89-100). Halifax: Association of Atlantic Universities.

Courtney, S. (2018). Why adults learn: Towards a theory of participation in adult education. Milton Park, Abingdon, Oxon: Routledge.

Dewey, J. (1933). How we think: A restatement of the relation of reflective thinking to the educative process. Boston: D.C. Heath.

Elliott, C. (2013). The impact of AACSB accreditation: A multiple case study of Canadian university business schools. Canadian Journal of Administrative Sciences/Revue Canadienne des Sciences de l'Administration, 30(3), 203-218.

Ewert, A., \& Sibthorp, J. (2009). Creating outcomes through experiential education: The challenge of confounding variables. Journal of Experiential Education, 31(3), 376-389.

Fink, L. D. (2013). Creating significant learning experiences. San Francisco, CA: Jossey-Bass.

Fung, D. (2017). A connected curriculum for higher education. London, UK: UCL Press.

Hamilton, N. (2014). Symposium: methods of teaching and forming professional identity. Regent University Law Review.

Holman, D., Smith, T., \& E. Welch (2009). Honoring experiential education. Honors in Practice Online Archive, 93, 211-218.

Ironside, P. (2004). Covering content and teaching thinking: Deconstructing the additive curriculum. Journal of Nursing Education, 43(1), 5-12.

Jaggars, S. S., \& Bailey, T. (2010). Effectiveness of fully online courses for college students: Response to a Department of Education meta-analysis. Community College Research Center, Columbia University.

Kayes, D.C. (2002). Experiential learning and its critics: Preserving the role of experience in management learning and education. Academy of Management Learning and Education 1(2), 137-149.

Killam, L., \& Carter, L. (2010). Challenges of the student nurse on clinical placement in the rural setting: A review of the literature. Rural and Remote Health, 10(3), 1523.

Knopp, R. (2006). Editorial: The challenges of teaching professionalism. American College of Emergency Physicians.

Kolb, D. A. (1984). Experiential learning: Experience as the source of learning and development. PrenticeHall, Englewood Cliffs.

Kolb, D.A. (2014). Experiential learning: Experience as the source of learning and development, $2^{\text {nd }}$ ed. Pearson Education, New Jersey.

Kolb, D.A. \& Fry, R. (1975). Towards and applied theory of experiential learning. In C.L. Cooper (Ed.), Theories of group processes. New York: John Wiley \& Sons.

Maher, P.T., \& Root, E.L. (2015a). Cape Breton University: Community Studies and Outdoor Leadership. Pathways - The Ontario Journal of Outdoor Education, 27(2), 33-35.

Maher, P.T., \& Root, E.L. (2015b). Learning to learn: Creating community before cramming in content. In J. Loxton (Ed.). Proceedings of the 2014 Association of Atlantic Universities Teaching Showcase; October 18 2014, Cape Breton University, Sydney, NS (pp. 53-59). Halifax: Association of Atlantic Universities.

Mikkonen, K., Elo, S., Kuivila,H., Tumikoski, A., \& Kaariainen, M.( 2016). Culturally and linguistically diverse healthcare students' 
experiences of learning in a clinical environment: A systemic review of qualitative studies. International Journal of Nursing Studies 54 (February 2016). 13-187.

Morgan, R. (2004). Perseverance: The story of Cape Breton's University College 1952-2002. Sydney: UCCB Press.

Nielsen, A. (2016). Concept-based learning in clinical experiences: Bringing theory to clinical education for deep learning. Journal of Nursing Education 55(7). 365-371.

Papadakis, M.A., Hodgson, C.S., Tehrani, A., et al. (2004). Unprofessional behaviour in medical school associated with subsequent disciplinary action by a state medical board. Academic Medicine, 79, 244-249.

Patterson, C. \& Snelgrove-Clarke, E. (2016). The significance of personal learning environments (PLEs) in nursing education: Extending current conceptualizations. Nurse Education Today, 48, 99-105.

Penger, S., Znidarsic, J., \& Dimovski, V. (2011). Experiential learning and management education: Empirical research and implications for practice in higher education in Slovenia. International Journal of Management \& Information Systems, 15(1), 23 34.

Reynolds, M. (1999). Critical reflection and management education: Rehabilitating less hierarchical approaches. Journal of Management Education 23, 537-553.

Salyers, V., \& Carter, L. (2010). Student and faculty satisfaction with a pedagogical framework: Research findings based on the ICARE model. Collaboration for Online Higher Education and Research (COHERE). Toronto, ON.

Salzman, D., McGahie, W., Caprio, T., Evan, E., Hufmeyer, K., Issa, N., Schafer, E., Trainer, J., \& Wayne, D. (2016). Use of a simulation-based capstone course to teach and assess entrustable professional activities to graduating medical students. Medical Science Educator, 26 (3). 453-456.

Sloane-Seale, A. \& Kopps, B. (2013). An aging workforce: A Manitoba perspective. Canadian Journal of University Continuing Education 39(1), 1-25.

Strudwick, G. (2015). Predicting nurses' use of healthcare technology using the technology acceptance model: An integrative review. Computers, Informatics, Nursing, 33(5),189-198.

Sung, Y. T., Chang, K. E., \& Liu, T. C. (2016). The effects of integrating mobile devices with teaching and learning on students' learning performance: A meta-analysis and research synthesis. Computers \& Education, 94, 252275.

Tomas, L., Lasen, M., Field, E., \& Skamp, K. (2015). Promoting online students' engagement in learning in science and sustainability preservice teacher education. Australian Journal of Teacher Education, 40(11). http://dx.doi.org/10.14221/ajte.2015v40 $\mathrm{n} 11.5$

Vince, R. \& Reynolds, M. (2007). Handbook of experiential learning and management education. Oxford: Oxford University Press.

Yardley, S., Teunissen, W., \& Dornan, T. (2012). Experiential learning: AMEE Guide No. 63. Medical Teacher, 34, e102-e115.

Young, O. (July 2, 2018). The privileges and challenges of teaching in professional programs. Retrieved from: https://www.facultyfocus.com/leadarticle-in-focus/the-privilege-andchallenges-of-teaching-in-professionalprograms/ 


\section{Biographies}

Lorraine Carter is the Director of the Centre for Continuing Education at McMaster University. Lorraine's current research interests include adult, health, and online education; health and educational services in rural and northern settings; aging and caregiving; and leadership.

Patrick T. Maher is Associate Professor and Chair of the Department of Experiential Studies in Community and Sport at Cape Breton University. Pat is a SSHRC University Research Chair (2019-2022) and one focus of his work is leadership within teaching and learning in higher education.

Leslie J. Wardley is Assistant Professor of Marketing in the Shannon School of Business at Cape Breton University. Leslie is a SSHRC Exchange University Research Chair in Social Determinants of Health (2019-2022) at Cape Breton University.

Kathy Snow is an Associate Professor of Education within Cape Breton University's School of Education and Health. Kathy is a CBU Teaching and Learning Chair in Open, Online and Blended learning (20172019) as well as a SSHRC Exchange University Research Chair (2019-2022). 